Juneau, Alaska, April $87 \mathrm{th}, 1916$.

Eagle River vining Company,

$$
k \times \|^{2-4^{\prime}}
$$

Macon, Georgia.

\title{
Gentlemen:
}

I am subultting herewith a general report on the properties orned by the Ragle River uining Company, and the adjoining groups of olatus known 8 s the Yankee Bagin Froperties, whioh you have recently arranged to consolidate under a new organization known as the gagle River Mines Oompany.

The following disoussion of the merits of these properties, as well as the rasults of tho past operations, is based upon my personal experienoe as superintendent of the ragle River uining Company from the year 1903 to 1910 , and from 1910 to the present writing in an advisory oapacity.

I am also attaching berewith brief report on this comblined group of olalms made out by Mr. O. P. Rogers, eyporintendent of the rensington vining company, who at one time ras employed as an englneer by the Eagle River yining Company and wo 18 familiar with all the detalls of the past wining operations.

Mr. Rogers' report, with the attached maps and photographs -111 serve to lilustrate the location of the combined groups, the status of the present derelopment, the position and amount of underground development, the detalls of actual production, and the proposed new derelopment and equipment program with detalled oosts and time eatimates.

As mentioned in Kr. Rogers! report, the original disoovery on whtoh the flrgt olaims of the Eagle River Group wero located was made in the year 1802 . Coneiderable attention was given to this disoovery in the Juneau Mining District on account of the character and value of the ore, and shortly afterwards an option was obtained from the looators by one $C$. D. Mallary, acting as agent in the Juneau District for certain interest fro Macon, Georgla.

At the request of Mr. C. D. Mallary, I made a preliminary examination of this outerop, in behalf of Rillam Ebner, of the Ibner dold yining Company, with whom I was employed as mine superintendent. My examination and report Indioated an outorop two hundred and fifty foot in length, varying from fivo to fifteon foet in width and having an average value of between $\$ 10.00$ and $\$ 15.00 \mathrm{per}$ ton.

The option held by $O$. D. Mallary was eventually exercised and a company, known as the gagle River yining company, was organized, in waoon, Georgla, to purchase and operate the wine. In the year 1903 I was of fered the managenent and in July of that year began active work in oonnection with the oongtruction and derolopment of the property.

Under the option it was neoessary to lmadiately build a 10-atamp 111 before any considerable devolopment work oould bo acoomplished, and within the period of nine montho allotted in the option.

The neoessary wharves, road frot the beach to the mine, seven miles in length, 10-8tamp mili with all acoessory buildings, aerial tramay, flumes and waterpover plant, mine 
bulldings eto., rere completed and operation began witbln the perlod, and such operation was conducted without interruption on through the year 1909. In 1908 an addition of ten stamp ws added to the milling plant. From 1909 until 1915 underEround develuprant ras carried on which will bo disousged la ter in this report.

The results of the underground and surface development of this oruperty as carried out during this perlod may be suremsized 88 foliows:

That may be conaldered as a mo-belt" in the main Juneau Gold Belt, localiy known as the Faglo River Belt, was determined and has been studled as eucb by the Geological Survey who heve mado a special report un this parbloular dis-

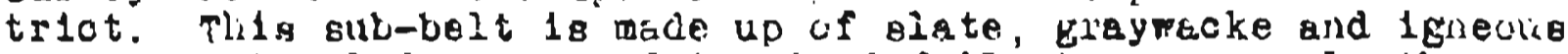
curtaota, the lude Byatem deterutried following a a rule the graywacke and tlack elete adjaoent thereto.

The ore ocours in oblmeys of varying lengths and Fldtb, In leneer in the elate zone, and aleo in what may bo described ag atringer ore bodteB. The alneral content lo made up of galena, pyrstictite, pyrite, a small amount of mo and copper culfides, argenlcul pyrite Fith guld, both free and ountelned in the wineral. The percentage if mineral throughout the belt 111 average about two peroent so that the ore ray be claseifled ag a free milliag and concentrating proposition.

The outcrops of the ohimeys, otringer zone and lenges ooourring siong the contact have veen determined the full length of the fagle Rlver oroperty and though the Yankee iasin pruperties, now urlted in iL1 n neti urganization, and through some oucoeeding olaims unned by other interests. The propertieg which are now to be brought into this oowbination hare a length on the ore zone of at least tro and one-balf miles. Jee attached meys.

On the Yankee Basin properties the onig develupment work of any consequenco has been conduoted in conneotion 1 th the cuntiluation of the Yanke Eoy vein consteting of a long crogocut tunnel with a griezl amount of drifting on the veln proper, and only open cuts and sme.ll tunnels have been made unon the continuation of the Panker ohlof lodo system.

The study of the formation and of the ore as show by this development work conclugirely proves that the geneele of the ore as rell as its characterigtion is the same 28 those of the Bliver Eor fasin lode sjotem Just back of Juneru. Tho only differance in the operation is that at Fagle river onis the ore ohlmneys themselves have been devoloped and mined while in the S1lver Bon 3asin belt the orerations hepe been orried out on a rery large scale end the pule atringer zone rorked en masse as a lor grade ore budy. Ho offort hes yet been made in the tegle P.1ver diotrict to study the otringer zone ereas with this iarge ettack of operation in view.

The bletory of the mining and willng operetions at Tragle River is as follows:

Shortly after development rork was started on the original outcrop a series of burface faulta rere encountered disolaoing the veln eystem horlzontally as well as vertidally from a fer to several hundred feot. Constant effort was todo through the yeare $1 \$ 04$ to 1912 to giet through and underueath this feulted system in what may be termed the "old sine", but 
28 development mork progreseed and better knowledge was obtained of this surface movement, and due to the position of the outorop relatife to the slope of the bill at this point, it finaliy beoame orldent it rould not alone be diffloult but unprofitable to continue operations from tbis seotion.

During thls period milling was cuntinued frow 1904 to 1910 in ounjunction 1 th this developaont mentioned abovo. $81 x t y-f 170$ thousand tons of ore was gent to the mill baving an average value of $\$ 5.90$ per ton. The broken condition of the ground on account of the faulting added a bigh peroentage of magte to the oro so that it mas reduoed in value accordingly. As a watter of feot, the arerage value of the quarts ained during this perlod rould aoproximate at least $\$ 10.00$ per ton.

Sight distinot onjmeys of ore rere determined in this sootion of the ground throughout whioh the development was oarried, the obuteo varying in length from forty to one hundred foet or wore, and having a width of frow a lea inobes to thirty leet. Values ranged from $\$ 2.00$ so $\$ 60.00$ per ton and on aocount of the fraotured natare of the ground leaching of the sulphides bad oooumed so that the ore mined in this seotion was highly free milling. Ninety-elght peroent extraction was obtained, the greater part of which was free and eagily amalgama ted.

Tho otockholderg of the Fagle River uining Company were men of amall means and had otrained themeelves to purchare and equip the wine. The purobaee prioe of the original mine alone $\mathbf{m a} \$ 150,000.00$ and the amount of development rork required in order to try and get out of this faulted zone into oolid formation entalied large expenditures prinolpally from the revenue obtained from milling operationo.

During the last three years, 1910 to 1912 inclubive, a Iinal effort vas wade in the old workinge to drive a long tunnel from the No. 5 bevel in the inine in an endeavor to locate tho vein in solid formation. A small amount of broken, fractured ore was encountered and wilod, bringing up the toral production to seventy thougand tons having an average value of $\$ 5.65$ per ton rrow the old ine operations, and a toral output of $\$ 372,612.35$.

It was decided by agreoment in 1912 to abandon the old workings and endeavor to locate the rein sjetem by meang of an adit tunnel, nor oalled the rlume Tunnel, some fivo bundred feet lower in elevation than the lowest tunisel of the old wine operations, and driven from suoh a posirion as rould aseure the location of tho formation underueath the surface glides and faulte.

The real ourpose of driving this tunnel wa to endeapor to locate the vein eyeter, and as it was limponelble for the Btookholdere of the oumpany to supply the neoeseary noney two or three of the otookholders in oonjunotion with myself and asilatant advanoed the woney for this tunnel.

The driving of the tunnel of course was a diatinet gamble on our part ag there was no absolute agsuranoe that we vould be able to find tbe voln, and further after finding it that tho ore rould continue to thig depth and hold $1 t^{8}$ value. Howerer, I was oertain that conditions existing in the belt as a wole wero entirely farorable and from the experienoe obtalned in the old mine operationg lelt sure that I oould through this tunnel locate the ore syetem and tbat the ralues and ore rould oontinue in depth.

This tunnel was driven during the yeara 1913, 1914 
and $1915 \mathrm{~g}$ tote longth of approxisately three thousand feet. The tinnel itself reg la the neture of a prospsot tunnel follonIng the formetion and oniy of guffiolent sise to permt of 1 to ountiuuance booguse the sum of money arallable for tho pusoose of dising this wan linited.

In the pezr 1924 the flyot 3 re vos encountered and durling tive toj suooeeding years turough continuation of the drift and cIJgecuts in conjunotion with dianond driling additlonal ofe was loguted and the Yankes Obief ore wo no defiattely reterwined beyond ang forament ar faulting aotion. The graymacke footrall, the charaoterlatio narsu band of graphltio blaok alate th the lenges or ohlmeye of ore proved conclusisely the looation and disoovery of the Yankes Chisf veln oystem in depth.

Durlag the yoarg 1914 and 1815 there thousand thres hundred fifty two tong frum the first ore budy having an arerage vaiug uf $\$ 15.34$ per tua, and tris thougand four hundred eleven tong. milled from the seoond ore body having an arsiage value of $\$ 5.07$ peI ton. Ths eeond ore body encountered a indiosted on ths map ses in a permanent and sol1d furmation. The flrat one still snored some indioations of surface. faults and displaoement.

In this permanent formation an ore body on the level of the tunnel one hundred feet in longth, hsoing an average - Idth of lous and one-bali foet, aseayed $\$ 13.12$ per ton. Diamond drill holes sulth of tile indlcated the ojntinuation of this o re far another two hundred fest and the breast golng northeast towards Yentee agaln, while in Ior grade quartg at tho prosent ting, is in the formation pruper and ahould enoounter tho otber ohtinega of jre originaliy digojpered and nined in the old work1nga. It was also shom by orossoutg that thare was what may be coneldered atringer one thirty-81x feet in widtb having an average value of $\$ 3.75$ per ton.

These vere no funds arallable to open up inls tunnel and dovelop this ner ore so that it oould be mined eropitably and in addition to thet it wes found at tis level there was

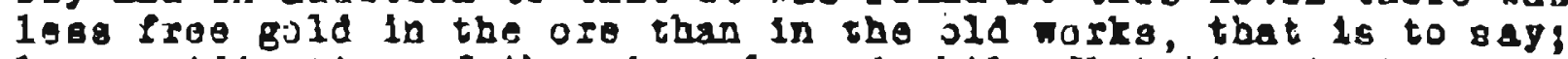
lesg uridization of the minerel, and whlle llotation testa proved o onclugively that $h 1$ gh extraction oould be made at a lor ocet on this ore there nas no money araliable to add tho neooseary equipment to the mliling plant. Therefore the oomparatively $10 \mathrm{r}$ oxtraotion ubtalned on thi. ore and the hlgh tallg made it unpropltable to continue operationg on the small soalo permisalble by the llalted development and alse of the tunnel.

It ras my oplalon and advioe that winlng operatiung should not be continued on this property without ner and propex flnanoing and proper developmed nort, and that before this $a$ ludertaken an flort ghould be rade to oonnolidate the adjoining Brjupe 80 there would bo a large onough area to make tbe wolo proposition attraotive to ner coney and, in addition, optione ehould be outalned and arrangenents ade so that the new money oould enter this nroposition on tho basis of a development prograx, manly; that the groups obould bo combined tnto a non oupeny worein fifty-ono percent or oontrolling interest ohould be offered to the new money for a oortain amount of desoribed dovelopment work.

After ounalderable diffloulty negotiatlons havo boen oonoluded to that ond and tho Eagle fiver Mlatag Compang 18 now for the firut time in a position to offer an attraotiro miniag proposition to aapital laterested in thr class of invertment. 
The fundamental elements of the proposition as it stands today are as follors:

Firat: A length of two and one-hall niles on the ore zone hae been brought together into one organisation. Outorope of ore are 1ndloaled throughout the totel elngth of this zone.

seoond yining opsrations oonduoted on tbo regle Miver elde $\$ 450,000.00$ on an average profltable grade of ore.

Third: The ore zone has been located on the cagle River olde boneath all burfece faulting and the ore hes been croven in depth, having a value bhown to be equal if not better than that uned on the gurfaoo.

fourth: A development program has beon lald out compromisting the driving of a rorking level whioh will at the eav time dorelop the ore zone. The meaning of this 18, vis whoever undertaker to drive this tunnel 111 be dolag a ploco of Pinal developwent work necessary to future-operstions and, at the same time, developing ore. Any unusual riak is elininated boouse if in driving this tunnel new ore 1 s dot enoountered from time to tiwe the proposition may be iropped without any material loge. On the othor band, if ore is enoountered in this development mork, ae I believe it 111 throughout the whole length of the ore sone, the continuation of the tunnel w111 be rarranted and on aocount of the great depth dained from this proposed adit tunnel a very large tonnage oan soon be dereloped and made aratlable.

The position of tals tunnel 1s the only proper way to attack thls whole lode aystem. The present equipment of the Tagle RIVer Vining Oompang's property inoludos nill, boarding house, transportation eyotem, warl, to., and is in oxoellent ahape, properly looated and cuffiolent to peralt nut alone the carrying out of the proposed development program but to permit of otarting tho atual mork lawediately althout the usual $108 \mathrm{~s}$ of tiwe in prelimiary nork exiating on wost properties.

The flotation tests oarried on prove concluglrely that the m111 equipaent up to five hundred tons dalls oapacity for thig ore oould be ingtalied at a ninimum expanse with a resulting bigh extraction and lon oogta. Mining and miling operations ooncuoted on the ore ohuter alone should be oarried out at a oost not to exoesd $\$ 8.50$ per ton, lnoluding talling $10860 \theta$, and if the etringer sones a ro worked on a large eole the oosts mould run about 1.00 to $\$ 1.25$ per ton.

Bydreleotrio porer for larger operationg 18 avallable in the distriot and there lo sufflotent poror for mall operations by the addition of a sall awount of vinter porer.

The proposition should be attrative to a group of men of reabonable means who are willing to driro an adt tunnel for derelopwent purposes with the possibility of developing a largo wine with a minus risk. In faot, all of the eseontial risk have already boen oliminated. The only question now open 18 the quantity of the ore which Nith this deteralned it $\mathbf{1 1 1}$ be poselble for suoh group of men elther to operate the mine themelves on a linlted eoale or 8011 it to one of the larger organieations, suoh as I a now working for, who would buy it and equip and operate the property on a large soale. It ghould be also noted that no payaents on the property are required do that no forfolture oan oodur as under the usual form of option.

Dnt1l this development is oompleted the property is not in shape to offer to one of the larger oining oorporatione $-6-$ 
mo as a rule do not conduot development work but there are numerous gall organlestiong or group of men who should be riling to undertake this development rork nith the poosibilit1es in olght.

From ay experienoe as aperintendent of the old oompany and the remits of operations ojnduoted theroin. I feel certain the drifing of this ads tunnol nould derelop a largo and profitable wine at an early dete. Bhort lateral diamond drilling sould be ornduoted in oonjunotion with the driring of the adt tunnel in order to looate and sample the ore bodiea oncountered.

My dutieB as anager of the Alask Gestineau Mining Dowpang are ouch that I have no timo to give this venture tho oonsideration nooeseary to lnterest oapital and it lo not got adranced to the polnt where the proposition as a whole would interest the people with whom I al assoolated.

I trust you $\mathbf{1 1 1}$ be able to bring this wole proposition to the attention of tho right kind of oapital and 1 you are buocoseful in oo dolng I w11l at all tines be to go lato further detalig 1 th them and glve any advioe or information which I have obtalded through ay experienco in oonneotion with your oompang.

I truat the data, maps and mterlal attaohed noreto $m 111$ be bufflolont to give you olear and goourate ldes of tblo whole proposition, not alone to yourselves but to the oapital you expeot to laterest.

Yours rery truly,

B. L. TBARE.

$B L^{2}$ - H

EROL. 
Ragle River MLing Company, Juneau,

$$
\text { A } 1 \text { a } \mathbf{x} \text {. }
$$

Gentlemen:

(At-the foquestiof of a report wa the oroposed toviopent of the aggle Rlver and Yenkee Aasin (Early-von1111ems) propertlea, (whtob: rooently-have agreed to oonsolidate a the ragle Rlzer ulnes Comang.)

The purpose of the folloring report 1e to ronder a degcription of the propertiee in regarde to their. geologioal fentures, 'hlstory, and present state of dereloprent; cta and

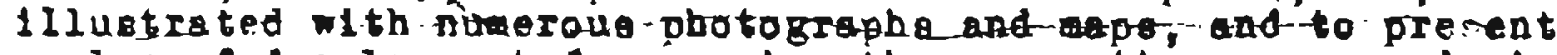
a plan of davolopment for opening the propertieg on a produolng bertar.

\section{GETRAL ETSCRITIIOA.}

The cagle River Hotng property I located at the head of ragle Alver, 25 mileg north-west of Juneau, 1 lask, and? milee iniand from Lynn Canal, and oonoeoted vitb tideneter-bra boree tramiay of easy grade. The warf 18 situated in Eagle Cove where rbarfage can bo oocured by any of the resele ply lag the trade in soutbeagtern Alaka.

This property ooneiate of 63 lode clalme whioh are looated along the atrike of the lode syatem and join on their north boundary the Early-Mckill lams goap of 24 olains, Fich are looated on a oontinuation of the sare lode eyeter.

The geological formation on the two propertie 18 eerentially the sane $>$ g that of the Alagka-Juneau and AlagkaGastineau sines, ond oonolots of quarte stringers, voing in an Interotratisled oerles of olay glates and grayracke alatea. Tho marked almilarity of the ore throughout the tro groups. Is rather conclustre that the ore rone 1 continuous throughout tholr length or for gbout 13,000 foet, and the rlob ore enoountered in tho slume tunnel (aee vap 4) lo further proof of 1te exteneion downard.

un the Early-yoll111aragoup, four main velng varylng in midth from 2 to 13 leet, gad carrying did valuev, are oxposed

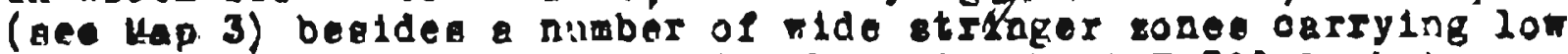
values. The strite of the velne bere 1 s about $\pi 50^{\circ} N$, but as they approson the Fagle River elde of the countain they turn more to the north and are broken and dlepleaed by ollde aotion and faulting.

Noet of the Rarly-hCFililame olatno lie on the divide at an eleration of 3500 to 3,000 feet, and are easily traoed oring to laok of regetation. The Eagie River oldo la covered with donee forest and tundra, making it diflowl to prospeot on the ourfsoe, oltbough the old wine rorkings and the ner flume tunnol proved the extenglon of the ore sone on tho cagle fiver side, and at a depth muob below the ort oncountered on the Early-xCN1111ane Group. 
PRESENT DEVELOFVETT OF TRR PROPERTIRS.

The carly-1:c 1111 ame property compriaes 22 clalms joining on their couth end the sagie River group, and all altuated at an elevation of over 1500 feat. Exteneive proppeoting has proved the extent of the ore zone over 6,000 leet, and tunvels driven on olalms joining the north end ilnes shor a continuation of the zone further atill. In one of thee tunnols, namely the Eluribus Unum, 30 inch atringer on the foot wall aesays over \$200.00 to the ton.

The 33 claimg comprialng the gagle River group join on tbeir north end the rarly-korilliame group and are looateo on the southern clope of the mountain which le oorered with dense veretabion ana tundra.

The orlginal or Eagle lode wa dlsoovered in 3902 , and consiated of ohain of taree ore chutes, wose total length wa 250 feet anci varied in width from flve to flfteen leet.

This ohute res underout by the uain tunnel driren at an elevation-of 1,000 feet. The ore encountered by the different tunnale drlien proved to be ohutes and lenese, dleoonneoted and faulted, and the whole area mined res broken and dieplaced, requiribe extensive tiobering.

In ordar to get out of this broken ground, the rlumo Tunnel weg otarted at an elevation of 555 feet and north of the

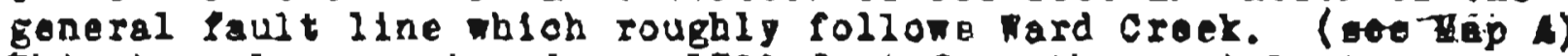
Th18 tunnel encountered ore 1700 foot from the portal, in a solid formation and proved the domnard extenalon of the ore zone to this level.

From 1904 to 1912 the old working produced 70,112 tons of ore averaging $\$ 5.65$ per ton and heving grog ralue of $\$ 396,830.00$. Being intned near the surface the ore was constaerably oxldized and free milling, giving a net reoovery of 80, . by analgamation in the mill. Oring to the broken oharaoter of the ground bo that the true value of the quarty ore ras nearer \$10. than $\$ 5.65$.

The ore enoountered in the flume tunnel wes not oxi-

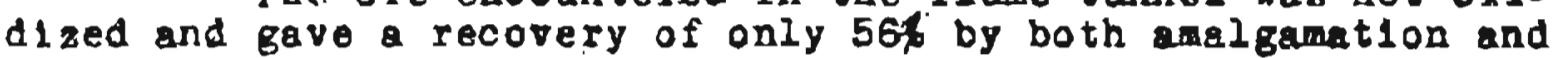
conoentration. However flotation teate have oroved that a recovery of orer 90\% can be made by thlo method.l a copy of there teats 18 appended in this repurt. The oondensed reaulte are a follone:

I Amalgamation of orude ore crushed through 65-megh, follored by flotation of tailinga.

Heada- Crude ore

0010

41.20

7.08

Stlver

Talla- Tinal

Txtraction
ent Ext.

34.18

82.82
0.75

0.18

0.57

75.47

II Crude ore oruehed through 150-weob, otralght flotat lon.

Fegd 2

Ta11B -

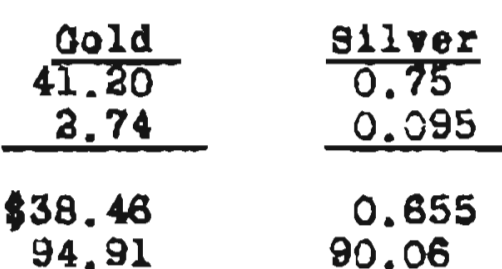

94.91

90.06 
During the years 1914 and 2915,4764 tone of ore, having a grose value of $\$ 48,319.00$ and hveraging $\$ 10.14$ merentined from the Flune Tunnel. A chart of the production and value of the ore mined from the old oorkings and flume tunnel 18 appended to this report.

The present improvoments and equpuent on the Esgle RIver Group oonelets of the following:-

\section{y1111ng Flant:}

Thte mill to oquipped with 20 etamps, amalganating plater and concentrating tables, and operated by mater porer. Boarding Flant:

Aocoumodation for 30 men.

3tore and warohouse:

Engineoring and As8gy opflce:

superintondent's Cottage:

Aset. Superintendent's Cottage:

Company House:

Blackemith shop:

Plume and plpe Llne for at1l power:

Tramiay to beach:

Therf:

This equipment is in good repal and considered as an agset in the estimates for developient.

FROPOSEN DEVTLOFYENT FP.OGRAY.

The inttlal development under this program provideg for the folloning lteme:-

1. Fer Adlt Tunnel. Th18 tunnel to be driven in the ore zone and etarted about 300 feet nortb of the present a121, at an eleration of 250 teat.

8. Reloe for rentilation.

3. Diamond ar1111ng to deternine the extent and value of the 2000 as the tunnel progresere.

4. Whe tools and equipaent to carrg on the work.

Thls is an 1deal developaent, as the tunnel w11l bo driven in a proved ore cone, and no expenditures are needed outolde of the Initial development, except a fully warranted by the development. The teras of the option on the carly-yon1111ame: 
property requite no nurchase price, and any paymente wade thereon Fili be from the nrocseds of the wining operations, providiag the developrent proves ratibfactory.

The supplementary deralopment 18 to be etgrted at auob a time as ore proven up by the devoloprent rarzants it. The oboracter of the eupplementary development depends upon tho nature of the ore encountered, it mey be either:

1. Narrow velne or lenees carrying hlgb ralueg, or

a. Hide stringer zones, carrying low valuer.

The expenditure on the inltial development 1111 be the eame in alther oabe.

The ectimate on nining 100 to 150 tone dally from narro hlgh grade veine (Plan A) provide for an all year round porer plant, the preaent rater porer development beling inadequete fot this tonnage; re-arraging the progent stamp nill as a flotation plant, and providing oufíalent alr oowprasmor oapaolty for the work, benldee necersary ohanges and addition to the pregent equipment. The estinate however ororldee for ns dovelopment In ore, it being oonsldered that the adit 18 driren in the ore zone and the oont of development be barne by the ore extraoted.

Under this plan it 18 entirely feasible thet the tunnel and diamond-drill proapeating Fili ind loate ore of sufflolent grade and tonnage to warrant the purcbaso and lnetallation of eouipment necersary for wintag this smouat before tbe intial derelopwent work is plnished.

The character of equipaent neoeggary for minlag 500 tons per day frop the eeound type of deposit (Plan B) differs radioglig fron the irat. It requirea very extensive oquipment and hleh initial expenditure. The tino neceseary to develop the rine to produce this tonnaze is neoesearlly much longer than in the lirat tyne.

Thls type of depoelt ip osaentlally the sawe as is mined by the Alaoka-Juneau and Alasta-Gastinoal Ming Companles near Juneau. The ohief value in thlo plan 11e in the 10 operating ooet. The expendituree for a $1000 \mathrm{H} . \mathrm{F}$. vater pover plant, and the ermotion of a 800 ton Motation $y 111$ are tbe larget itens. Thle poner olte ia eraliable, and can be developed.

of the tro plane ooneidered, Plan A. offere the leget expenditure and oulokest returne on the money inverted. The edvipablitty of operating on plan B. can only be determined by the derelopment in the new tunnel.

\section{Appended to this Report are the followings-}

1. Goet estivate - Plan A. Mining 200-150 tone per day, from

narron higt grade

3. - Flan B. U1ninz 500 ton per day, from rido 10\% grade etringer zone.

3. Detalied ltemg of expendtiture on Plan A.

4. Produotion Chart - Sagle rilier Hinlng Oc.

5. Reoord of Plotation Fegts on Ragle River, ore.

6. Nar 1. - Oaologloal vap of Juneau Dietrlot.

7. a. - Ragle River Dlatriot.

8. 3.- " " Orose seotion of Lagie Rlver

8. 4. - Iagle River xine and Aseay yap.

10. Fumerous photographe of the property.

Yours truly,

o.P. Rogightheer. 
TAGLE RIVER MINING CONPANY

ORE PRODUCTION \& KILLING DATA.

EAOLT RIVER NINE

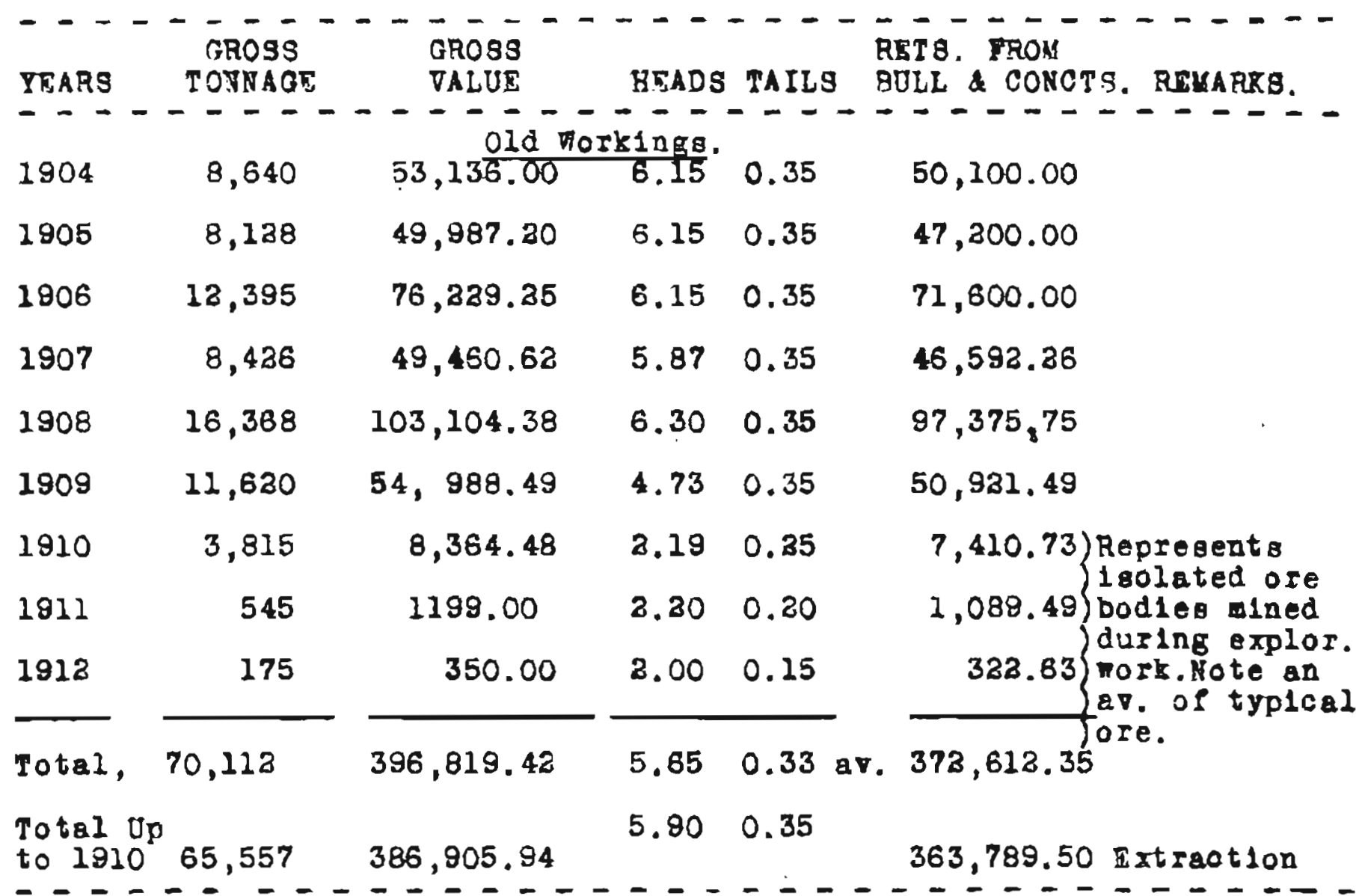

New Morkings - Plume Tunnel.

1913 M111 not running this year.

$1914 \quad 3,353 \quad 36,095.03 \quad 15.34 \quad 6.75 \quad 20,225.36$

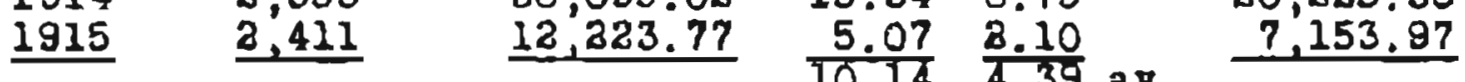

Total $4,764 \quad 4$ P.,318.79 $\quad-\quad 27,379.33$ Fxtraot.56.5\%

\begin{tabular}{l} 
Grand \\
Total, $74,876 \quad 445,138,31$ \\
\hline
\end{tabular}

Total

excluding

$1910,11,12$.

$\begin{array}{lllll}70,341 & 435,234.73 & 6.18 & 0.62 & 391,168.83\end{array}$ 
Aprl2 26, 2915.

TTAF COPFTR COBIATY - ARTITP PMART.

FLOTATION DEPAPTI:EHT

TRST PATE ON TBK EAOLE RIVER YININO COMFARY GOLN ORE.

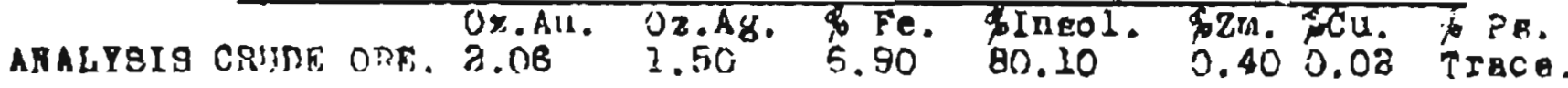
AMALOALATION TEST

Heading, Oz.AU. Oz.Ag. ARD.Rzt'r AU. APD. Extn.Ag.

$\begin{array}{lllll}\text { getraction, } \quad 1.15 & 0.17 & 55.83 \% & 11.23 \%\end{array}$

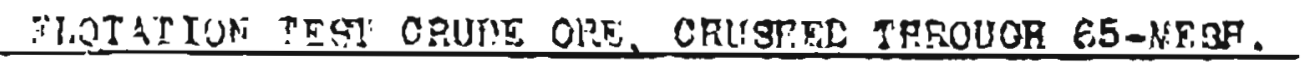

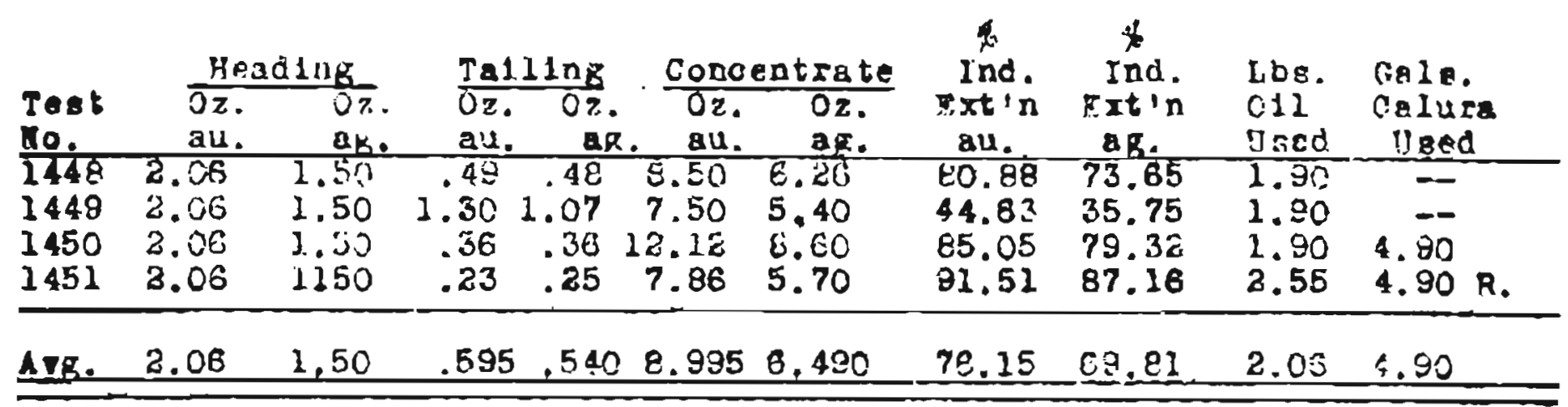

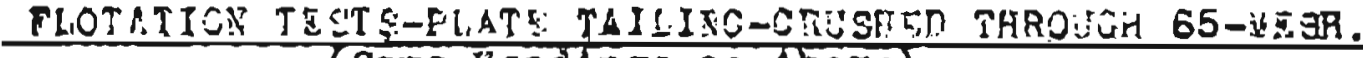
(same jeadings as hbove)

\begin{tabular}{|c|c|c|c|c|c|c|c|c|c|c|c|}
\hline $\begin{array}{l}1454 \\
1455 \\
1480 \\
1481 \\
1488\end{array}$ & $\begin{array}{l}.91 \\
.91 \\
.91 \\
.91 \\
.91\end{array}$ & $\begin{array}{l}1.32 \\
1.33 \\
1.33 \\
1.53 \\
1.53\end{array}$ & $\begin{array}{l}.42 \\
.36 \\
.38 \\
.40 \\
.33\end{array}$ & $\begin{array}{l}.42 \\
.32 \\
.34 \\
.40 \\
.36\end{array}$ & $\begin{array}{l}4.16 \\
4.68 \\
2.53 \\
3.10 \\
8.88\end{array}$ & $\begin{array}{l}6.40 \\
6.32 \\
3.79 \\
5.74 \\
4.48\end{array}$ & $\begin{array}{l}58.89 \\
71.65 \\
74.27 \\
63.52 \\
72.04\end{array}$ & $\begin{array}{l}73.23 \\
79.85 \\
81.79 \\
75.16 \\
79.31\end{array}$ & $\begin{array}{l}1.80 \\
1.70 \\
3.74 \\
3.84 \\
3.84\end{array}$ & $\begin{array}{l}4.80 \\
4.30 \\
7.30 \\
7.30 \\
7.30\end{array}$ & $\begin{array}{l}0-6 \\
R \& 9 \\
R 8 \\
0-6 \\
0-6\end{array}$ \\
\hline AVg. & .91 & 1.33 & .354 & .368 & 3.520 & 5.404 & 67.93 & 77.58 & 3.00 & 6.34 & \\
\hline
\end{tabular}

FLOTATION TEST - ORUDE ORE - ORUBHED THROUOR 150 4E 34

\begin{tabular}{|c|c|c|c|c|c|c|c|c|c|c|c|c|}
\hline \multicolumn{4}{|c|}{ Reading } & \multicolumn{3}{|c|}{ Ta11ling } & \multicolumn{3}{|c|}{ sonoentrate } & \multirow{2}{*}{$\begin{array}{l}\text { IND. } \\
\text { EI'N } \\
\text { AU. }\end{array}$} & \multirow{2}{*}{$\begin{array}{l}\text { IVID. } \\
\text { EXT' } \\
\text { Az. }\end{array}$} & \multirow{2}{*}{$\begin{array}{l}\text { LB\}. } \\
\text { oIL } \\
\text { OBod }\end{array}$} \\
\hline 00 & $\begin{array}{l}\text { Oz. } \\
\text { Au. }\end{array}$ & $\begin{array}{l}\text { Ug. } \\
\text { Ag. }\end{array}$ & $\begin{array}{l}F^{-7} \\
\text { re. }\end{array}$ & $\begin{array}{l}\text { Uz. } \\
\text { Au. }\end{array}$ & $\begin{array}{l}\mathrm{Oz} \\
\mathrm{Ag} .\end{array}$ & $\begin{array}{l}76 \\
50 .\end{array}$ & $\begin{array}{l}\text { Jz. } \\
\text { iu. }\end{array}$ & $\begin{array}{l}\mathrm{O}_{2} . \\
\mathrm{A} \text {. }\end{array}$ & re. & & & \\
\hline & $\begin{array}{l}2.00 \\
2.08\end{array}$ & 1.50 & & & & & & & & & & \\
\hline
\end{tabular}

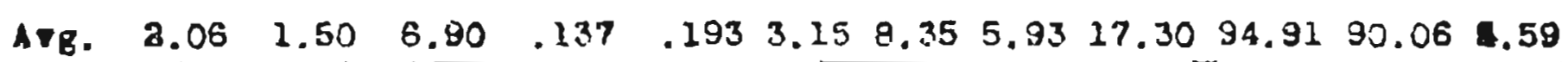

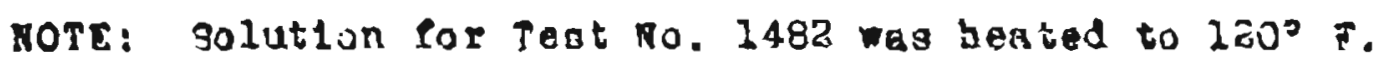


UTAF COFFER DOMFANY - ARTRUR PLANT

EXFERINETIAL \& RESEARCH DEPARTUENT

FLOTATION TESTS JURT 18th, 1915.

\author{
HATERIAL: \\ Orude ore frow the ragle RIver uning Co., Liaka.
}

RATUKF, OF TERT \&

A Berles of eleven flotation tegts was run on tale ore, four of whlob were on orude ore orushed to pas 65 mesh poraen; tro on orude ore crushed to pase 250 mesh ecteen, and fire testo on the talling frow plate analgamation tegt in whioh an apparent extraction of 55.836 of the gold, and $13.33 \%$ of the allver was effected, maxling talling whicb asajed 0.91 oz. gold and 1.33 oze. oliver per ton. All totation teets vere made ith the janney Flotation testing oblne, using standard flotation 1018 and reagents. 500 gram of pulrerleed ore used in eaob plotation test.

YETRODS AND BISOUSSIOR:

The ore was recelved, was orushed to pase 65 wesh screen and a saple taken for heading agay and analyal, whiob was used 28 a bas for all calaulationa. Inother portion ra taken for a plate analgamation test. Tho remalnder belng left for plotation teats on the orude ore. A portion of this was subsequentig orusbed to pase 250 mesh screen.

All tests rere of flre minuter curation, two produots only boing produced, 12 , oonoentrate and tallinge, all testb were conducted at atmospherlo temperature, oxcoot No. 1483, In rhiob tho colution mas heated to $130^{\circ} \mathrm{F}$.

The awount of both otis and calura, indioated in the teats 18 the quantity uoed per ton of ore.

RAMR OF OILB EMPLOYED IN TESTS

L1ght oll coal tar
L1ght oll coal tar
Reconstructed store 011,
Racopinol
Chesapeske Fine
Reco No. $\exists$,

Coal tar is produced by the deetruotite diat112ation of coal, as by-product in the manufacture of gas. thls plant.

Reoo stove 01118 a replned wineral ofl recongtruoted at

Chesapeake plne oll 18 producod in the destruotite diatlilation of pluevoods and recoplnol 1 s produced by reconotruoting pine oll at thle plant.

Reo0 Ho. 9011 is produoed by reconstruoting flotation 011 Bo. 9 mbich 1. produced in the rellalng of petroleum oll. 
TEgT No. 2448 :

Crude ore thru 65-meah; 1.9 1ba: of light o11 ooal tar added at start of teat. Produced a good froth oarrjing wontly Iron eulphides.

TEST NO. 1449:

J rude are, thru 65-meab; uged 1.9 168. 11ght oll coal ter added at beginning of test. (see tebt No. 1448.)

TEST 10. 1450 :

Frude ore, thru 65-nesh. Used 1.9 1ba. 21ght ofl conl tar and 4.9 taliong of calura, tiloh made tailing alwogt entirely freo rroin sulphlder. In this cabe eapecially, the tal ling looked rery olean.

TEBT No. 1 /51!

Crude ore, thru 65-meah. Used 8.55 lbs. of compounded $80 \%$ Reoo-etore, and aOt recopinol o11. Algo 4.8 gals. of calura. The talling appensed to be rory fres from oulphides.

TEST NO. 1451

Flate talling thru 65-megh; 1.9 lba. of $11 \mathrm{ght} 011$ coal tar and 4.9 gale. of orlura were ueed. Th1B produced a good frotb the talling did not appear to be as clean as with reoonstruoted ofle.

TEET RO, 1455 ,

Flate talling, thru 65- regh. 1.7 1bs. of compounded 804 reco-btove and aof recopinol with addition of 4.9 gals. of oalura used. Talling apnarentiy oleaned up rell.

TEST NO. $1480:$

P late tatling thru 65-meob. Jeed 3.74 1b\%. of compounded 806 reco-gtore oll and $30 \%$ roooplnol, w1th 7.3 gele. of oalura. The talling wae apperontly entirely froe frou sulphides.

TE8T NO. 1481 :

Plate taling thru 65-mesh. Uood compounded oll of $90 \%$ $11 \mathrm{ght} 011$ ooal tar and $10 \%$ obearpeake pine, ith addition of 7.3 galb. of calura; this gave a good notlve froth and apparently Flosted all of the mineral.

TEST RO. 1482,

Flate talling thru 65-mesh. Used 3.84 Ibs. of compounded 906 11ath conl tar $d l$ and 104 obesapeake plne. Aleo added 7.3 gals. of calura. The solution wa heated to $130^{\circ}$. It ba been found adrantageoue in coine caser mith gold ores to beat the solution, honever, It lo apnarently of no benofit in this caro.

TrgT 10. 1539 :

Orude ore thru 150-asah. Used 4.25 lbb. Of light oll cosl ter (No. 798-G-80) and 0.7 IbB. of chesapeake plne 1 th 19.8 galo. of calura. A good froth wa producod and apparently ade clean talinga.

TEST Y. 1537:

Orude ore thru 150 mesb. Used 3.98 1bo. of reco No. 9 plotation 011,0.25 108. of rocopinol, and 14.4 gale. of oalura. obtalned g good rion, blaok froth with talling apparently free from eulphides.

It should be noted that the percentage indloated extraotion chown in the tabulsted atateent for teets, Fon. 1464, 1455, 1480, 1481 and 148 a sow the Indloated extraction in the flotation test only, but as these teets wero on the talling fron plate analganation test, the total peroentege apparent extraction, osloulated from the original orude ore arsay and the ultimate plotaston telltags, showlag the combined regult of amalganation and bubequent flotation treatment is hereith glven. 
Test Mo.

\section{4}

1455

2480

1481

1482

Arerage ogloulated from A rerage Ta111ng.

\section{Peroent}

Aง. 79.81

85.44

84.47

$80.5 B$

83,98

82.82

\section{Apperent Extreotion}

A. 72.00

78.67

77.33

77.33

78.00

The teete how that orer onemalf of the gold can be saved by plate amalgamation, and by subequent treatment of the plate talllng by flotation a mucb better extraotion 10 obtained than by $120-$ tation alone, on pulps orushed to the same degree of finenese.

The recovery of approxlmately ono-hal of the gold content by amaleamition 18 a decided advantage, as the smeltera fould not pay full value for the gold content ia the conoatrate.

The bent average regults were obtained on pulp orughed to pars 150-mesh, and the coonomic value of thlo lacreased extraction by finer crusbing w11 be best asoertalued by looel and plsnt conditlons, and the degree of flnenese to which lt w111 be adrantageous, or eoonomia to reduce tho ore rould be arrived at by oaloulation of the inoreased oost ( 1 th posalble reduction of oapacity of plant or additlonel equlpment neceseary) and the lneroased extraotion made posotble by the flne orushlng.

The results of these tosts would tend to bor that a part of the golo 18 elther in some other forw than free or a aboolated vith sulphider, or lo so Inely divided and diseonlated thru the gangue that it is not freod 1 th oruahing thru 65-mesh, a the plotation tallinge, in every oare appeared to be entlrely freo frou oulphidos and the plate talling should contain rery littio free gold. It Io most reasonable to suppose tbat it is the extreneds fine dirlsion of the gold ribtoh would only be Breed by finer oruobing than B5-meab.

These results oould doubtless be bettored in the large waolnes, oo it 18 obvious that thle ore bes pood poselbilities in treatment by flotation.

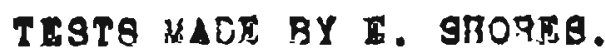

